\title{
TERRITORIAL DIVERSITY OF AVAILABILITY OF PUBLIC SERVICES IN POLAND
}

\author{
Dorota MIŁEK \\ Faculty of Management and Computer Modeling, Kielce University of Technology; dorothy@tu.kielce.pl, \\ ORCID: 0000-0002-2358-461
}

\begin{abstract}
Purpose: The nature of contemporary development processes determines the development of the area of public services, which is related to the distribution of these services and is of interest to public sector economics. The state's key commitment to its citizens is to guarantee adequate availability of public services. It is an important issue that determines the quality of life of the citizens and determines the level of social and economic development of territorial units. The aim of this paper is to analyze and evaluate inequalities in access to selected public services in Poland from a regional perspective.
\end{abstract}

Design/methodology/approach: To assess the level of availability of selected public services in Poland, Hellwig's synthetic indicator was used, which made it possible to indicate the ranking of voivodeships in terms of availability of public services. The research is complemented by the Ward's clustering method, which was used to identify clusters of territorial units with a similar level of availability of the analyzed services. The research used data made available by the Statistics Poland (GUS), including the Local Data Bank and statistical studies: Use of information and communication technologies in 2014 (orig. title: Wykorzystanie technologii informacyjno-telekomunikacyjnych $w 2014$ roku) and Use of information and communication technologies in 2018 (orig. title: Wykorzystanie technologii informacyjno-telekomunikacyjnych $w 2018$ roku). The analysis concerns the years 2014 and 2018.

Findings: Regions of Poland are characterized by a diverse level of availability of public services. The analysis allowed to identify the regions with the highest, high, low and very low level of availability of public services. The distance between the highest and the lowest ranked voivodeships indicates quite significant territorial inequalities in access to public services, although it has slightly decreased throughout the analyzed years.

Social implications: The study of availability of public services is an important component of the assessment of the level of social and economic development of territorial units and the standard of living of local communities. Therefore, it is justified to determine the essence of spatial diversity of the level of availability of public services, which play an important role in shaping the level of social and economic development of territorial units and influence the implementation of development priorities of the country and the European Union. The development of public services requires identifying existing barriers in the area of public governance as well as possibilities for their improvement and then proposing a set of instruments to improve the service management process. 
Originality/value: The results of the research can be used in the process of management of public services by public administration units in the context of increasing the universal availability of these services and improving their quality. The results of the analysis may provide a source of knowledge for both national and regional economic policy actors as well as European Union decision-making bodies in the area of public support to improve the availability of public services in the next development programming perspectives.

Keywords: public services, availability of public services, Hellwig's method, Ward's method, regional diversities.

Category of the paper: Research paper.

\section{Introduction}

The nature of contemporary development processes determines the development of the area of public services, which is related to the distribution of these services and is of interest to public sector economics. The availability and quality of public services determines the living standards of the citizens and determines the level of social and economic development of territorial units. Ensuring adequate availability and high quality of public services is an important commitment of the state to the local community and is linked to a continuous effort to increase the effectiveness of both the service activities and the use of public funds (Kos, 2015, pp. 147-159).

The aim of this paper is to analyze and evaluate inequalities in access to selected public services in Poland from a regional perspective. The analysis concerns the years 2014 and 2018. Two methods were used to assess the level of availability of selected public services in Poland: Hellwig's development measure (Hellwig, 1972, pp. 115-137) and Ward's clustering method (Ward, 1963, pp. 236-244). On the basis of a synthetic indicator, the first method allowed to rank voivodeships in terms of availability of public services, while the cluster analysis was used to identify groups of territorial units with a similar level of availability of analyzed services. The subject of analysis in this article is the territorial aspect of diversity in access to public services in 16 Polish voivodeships in the years 2014 and 2018. A set of diagnostic variables was used to characterize the issue in a complete manner. The set was shaped on the basis of substantive-formal and statistical criteria. The issue of availability of public services was analyzed in the scope of the entire system, using the Local Data Bank of Statistics Poland (Bank Danych Lokalnych GUS) and statistical studies: Wykorzystanie technologii informacyjnotelekomunikacyjnych w 2014 roku and Wykorzystanie technologii informacyjnotelekomunikacyjnych w 2018 roku (Wykorzystanie technologii..., 2014; 2018). In order to achieve the research objective, special attention was paid to spatial diversification in the level of availability of public services in the analyzed regions. The analysis allowed to identify the regions with the highest, high, low and very low level of availability of public services. 


\section{Public services - conceptual scope}

The public administration performs "the duty to provide public and social goods in the form of public services" (Dylewski, and Filipiak, 2005, pp. 451-454). The research objective adopted for the sake of this paper and its title obliges to present the essence and availability of public services. Services are often understood as manifestations of human economic activity of an intangible nature, which are characterized by interactions between the recipient and the service provider. Public services, which are a specific category of services available to the general public, are aimed at meeting important social needs ${ }^{1}$.

The level of availability and quality of public services are important criteria which determine both the standard of living of the citizens and influence the attractiveness of a particular territory as a workplace, decisions on the choice of place of residence and the location of external investments. In most countries, ensuring the availability of high-quality public services is treated as one of the basic tasks of the state and is an important factor for local, regional and national socio-economic development. The importance of public services for economic development, social cohesion and combating social exclusion is emphasized both at the European level (European Commission, 2007) and at the national level (National Strategy of Regional Development 2030..., 2019). It should be stressed that despite repeated references in the National Strategy of Regional Development to quality, availability and importance of public services, no definition of said services was included (National Strategy of Regional Development $2030 \ldots, 2019)^{2}$. At the regional level, the Polish voivodeships also very frequently refer to the category of public services in terms of prepared development strategies, together with the need to guarantee their high quality and availability.

A variety of definitions of public services can be found in the literature. The term is understood as a system of municipal, social and administrative services, aimed at satisfying the needs of local communities, in which state and local government administration entities are of significance (Dylewski, and Filipiak, 2005, pp. 451-454). Public services are therefore services related to the provision of public goods, which are characterized by the impossibility of excluding any member of the local community as their potential recipient (Flejterski et al., 2005). Some definitions of public services emphasize the obligation of the state to its citizens. An example is W. Wańkowicz's definition of the issue, who defines public services as tasks serving all citizens of a given local government unit, which form a list of activities and undertakings of a varied nature (Wańkowicz, 2004, p. 2).

\footnotetext{
${ }^{1}$ Public services interchangeably called social services, public utility services or services of general interest.

${ }^{2}$ Specific Objective 3 in the National Strategy of Regional Development 2030 was specified as: Improving the quality of management and implementation of territorially-oriented policies, and as part of the objective as an intervention direction was specified as Objective 3.3: Improving the organization of public service provision (National Strategy of Regional Development 2030..., 2019).
} 
B. Kożuch and A. Kożuch also emphasize that public services are the services which are aimed at pursuing the public interest, understood as serving a higher purpose, the most important from the point of view of society (Kożuch, and Kożuch, 2012, p. 33-36).

Public services are a specific type of services, and therefore are characterized, regardless of the adopted definitions, by all the general features of services, i.e.: immateriality, indivisibility, spatial determination, diversity, lack of possibility to acquire ownership (Pine, and Gilmore, 2013, p. 42; Niedzielski, 2011, pp. 113-114). However, as B. Ziębicki (Ziębicki, 2007, pp. 149$165)$ points out, due to the specific nature of these services, they have a number of additional features which distinguish them from other types of services which are not considered public. Therefore, the following specific properties can be pointed out as suggested by L. Borowiec (in addition to those mentioned above): inability to accumulate and store, lack of exclusion from the group of recipients, public utility, and the fact that each new recipient does not contribute to the infringement of the rights of others ${ }^{3}$.

In order to achieve the purpose of this study, it has been assumed that public services constitute a set of various types of services which are performed directly or indirectly by state authorities for the benefit of all persons residing in a given territory (Wańkowicz, 2004).

The clarification of the definition of public services is done by the adopted classifications of their individual types. In Polish conditions, the classifications refer primarily to the scope of services provided. One of the most frequently described divisions of public services in literature is classification according to generic criterion. Taking into account this criterion, B. Kożuch and A. Kożuch distinguish the following (Kożuch, and Kożuch, 2012, pp. 40-44):

- administrative services - directly related to the performance of administrative activities; they include the following types of services: issuance of documents, permits, concessions, decisions, entering into a database, keeping records;

- social services - are directed at the development of society and meeting social needs, related to the implementation of public tasks in such areas as: health care, education, culture, physical culture and recreation, social assistance and care, counteracting unemployment, housing, public safety;

- technical services, which concern the following areas: transport - services and infrastructure, waste management and maintaining cleanliness and order, cemetery maintenance, heating, energy production and supply, public greenery.

The presented classification of public services was the basis for the selection of features adopted for the study of availability of public services in the regions of Poland. This availability is one of the attributes of quality of public services. This concept refers to the degree of ease

\footnotetext{
${ }^{3}$ M. Czerska approaches the attributes of public services in a slightly different way and includes the following among the specific features of these services: susceptibility to political and social changes, competitiveness in the sphere of public services, social and economic consequences, obligation to use services by the client, subjective perception and evaluation, financing of public services by the buyer (indirectly through taxes) (Czerska, 2005, pp. 5-13).
} 
with which service users gain access to goods, services and places of activity (e.g. employment, education, health care, administration, etc.) (Koźlak, 2012, p. 172).

Availability is also highlighted in the government document Dostępność Plus 2018-2025 (Eng. Availability Plus 2018-2025) and it means a feature of the environment (physical space, digital reality, information and communication systems, products, as well as services) that enables all people (even with physical and cognitive difficulties) to use it on an equal basis. The programme focuses on ensuring availability by removing existing restrictions, which will ultimately guarantee reaching a larger group of potential recipients, opening up to new users, customers, beneficiaries and contributing to increased recognition and activity on the market (Dostępność Plus 2018-2025, 2018).

Public services can only be considered available if every citizen can use them and if they meet the following requirements (Kos, 2015, pp. 147-159; Wojciechowski, 2012, p. 72):

- the provision of the services is continuous and uninterrupted, e.g. electricity or water from the supply networks, telephone services, etc.

- the services are characterized by uninterrupted access and the possibility of continuous use,

- the level of safety of the services is constantly being increased,

- continuous efforts to increase availability and expand the range of services provided,

- the services are provided with the goal to constantly improve their quality.

It should also be stressed that the degree of availability of public services will depend on citizens' assessment of their quality. The availability of public services, understood as the possibility of using services, is a key determinant of their quality which is considered by the recipient (Wańkowicz, 2004) ${ }^{4}$.

\section{Methods of analysis and selection of research features}

In order to examine the regional variation in the availability of public services in Poland, the Z. Hellwig's development pattern method was used, which belongs to the group of taxonomic linear ordering methods (Hellwig, 1972, pp. 115-137). In this method, the assessment of the level of a multifeature phenomenon is carried out on the basis of an aggregated synthetic indicator, which is the basis for the hierarchy of the examined objects.

In the process of assessing the availability of public services in Polish voivodeships, the division of public services by type was used. The variables distinguished within the three types of public services (administrative, social and technical) allow building a synthetic

\footnotetext{
${ }^{4}$ For M. Wańkowicz, availability of public services means providing them fairly and equally to all citizens (Wańkowicz, 2004).
} 
measure of the availability of public services in individual regions. The procedure for constructing the synthetic indicator included the following steps:

1. Selection of potential diagnostic variables, which was based on substantive, formal and statistical criteria (Strahl, 2006). A set of diagnostic ${ }^{5}$ variables consists of stimulants and destimulants, however, the latter were replaced with stimulants ${ }^{6}$.

2. In order to obtain comparability of diagnostic variables, the values of individual indicators were normalized. It means that it was necessary to devoid variables of their natural units. The classical standardization of values of variables ${ }^{7}$ was used in this paper, according to the following formula (for stimulant) (Młodak, 2006; Zeliaś, 2000; Panek, 2009):

$$
Z_{i k}=\frac{x_{i k}-\bar{x}_{k}}{s_{k}} \quad \text { for }(i=1, \ldots, n ; k=1, \ldots, m)
$$

where:

$I$ - set of stimulants,

$Z_{i k}$ - standardized value of feature $k$ for voivodeship $I$,

$x_{i k}$ - value of feature $k$ in voivodeship $I$,

$\bar{x}_{k}$ - arithmetic mean of variable $k$,

$S_{k}$ - standard deviation of variable $k$,

$m$ - number of variables,

$n$ - number of voivodeships.

3. On the basis of standardized variables, the pattern of availability of public services was determined (abstract object $P_{0}$ ). It is characterized by the highest values for the stimulants and has standardized coordinates:

$P_{0}=\left[z_{01}, z_{02}, \ldots, z_{0 k}\right]$

where:

$Z_{0 k}=\max \left\{z_{i k}\right\}-$ when $x_{k}$ is a stimulant.

4. Calculation of the distance of each object (region of Poland) from the $\mathrm{P}_{0}$ pattern using the Euclidean metric (formula 3):

$$
\mathrm{c}_{\mathrm{i} 0}=\sqrt{\sum_{\mathrm{k}=1}^{\mathrm{m}}\left(\mathrm{z}_{\mathrm{ik}}-\mathrm{z}_{0 \mathrm{k}}\right)^{2}} \quad i=1,2,3, \ldots, n
$$

\footnotetext{
${ }^{5}$ The selected variables were treated as equal, assuming a unit weight system.

${ }^{6}$ In the article, stimulation of features using the transformation in the form of reversal of values of features according to the following formula was applied: $X i=\frac{1}{X i^{D}}, i=1,2, \ldots, n ; j=1,2, \ldots, m[22]$.

7 The standardization was carried out taking into account the arithmetic mean and standard deviation determined for the whole research period. Thus the synthetic measure of availability of public services can be comparable over time. In this way the analysis takes on a dynamic character (Zeliaś, 2000).
} 
5. In order to normalize the value of $d_{i}$ indicator, a relative taxonomic measure of development was constructed, which was calculated according to the following formula:

$$
d_{i}=1-\frac{c_{i 0}}{c_{0}}, i=1,2,3, \ldots, n
$$

where:

$$
c_{0}=\bar{c}_{0}+2 \cdot s_{0}
$$

$\bar{c}_{0}, s_{0}$ - arithmetic mean and standard deviation of $c_{i 0}(i=1,2,3, \ldots n)$ sequence;

$d_{i}$ - synthetic indicator;

whereas:

$$
\bar{c}_{0}=\frac{1}{n} \cdot \sum_{i=1}^{n} c_{i 0}
$$

and

$$
s_{0}=\sqrt{\frac{1}{n} \cdot \sum_{i=1}^{n}\left(c_{i 0}-\bar{c}_{0}\right)^{2}}
$$

The synthetic measure of development $d_{i}(4)$ obtained as a result of the calculations assumes values from 0 to 1 range. The closer the value of measure $d_{i}$ is to 1 , the less distant the object (region) is from the pattern and has a higher level of availability of public services.

The calculated indicator was used to rank the regions in terms of the identified level of availability of public services. The value of the taxonomic indicator made it possible to divide regions into four main groups in terms of the level of availability of public services. The groups of voivodeships with the highest, high, low and very low level of availability of public services were distinguished, classifying them according to the following ranges (Zeliaś, 2000):

I voivodeships with the highest level of availability of public services, $d_{i} \geq \bar{d}_{\imath}+S_{d i}$;

II voivodeships with a high level of availability of public services, $\bar{d}_{\iota} \leq d_{i}<\bar{d}_{\imath}+S_{d i}$;

III voivodeships with a low level of availability of public services, $\bar{d}_{l}-S_{d i} \leq d_{i}<\bar{d}_{l}$;

IV voivodeships with a very low level of availability of public services, $d_{i}<\bar{d}_{\imath}-S_{d i}$. where:

$d_{i}$ - value of the synthetic indicator;

$\bar{d}_{i}$ - arithmetic mean of the synthetic indicator;

$S_{d i}$ - standard deviation of the synthetic indicator. 
The analysis with the use of the linear ordering method is complemented by the spatial classification of regions due to a similar level of availability of public services in Poland by means of cluster analysis. It assumes the segmentation of data in order to extract homogeneous objects from the studied population. Hence the division of a group into individual groups is carried out in such a way as to obtain clusters in which the elements in the same group are similar to each other and at the same time different from the elements in the other groups (Gatnar, and Walesiak, 2004).

Ward's method, which is one of the hierarchical methods of object classification, was used to group voivodeships into clusters. It differs from other hierarchical methods in that the analysis of variance is used to determine the distance between clusters. Minimizing the sum of squares of deviations within clusters is key in the application of this method. Thus, Ward's method ensures homogeneity within clusters and heterogeneity between clusters, and therefore is considered to be most effective. It should be stressed, however, that it tends to combine a relatively small number of observations and to distinguish clusters of similar size (Ward, 1963, pp. 236-244; Strahl, 2006; Młodak, 2006; Marek, 1989; Szkutnik et al., 2015).

The research was carried out on the basis of standardized variables, and the Euclidean distance was used to form clusters. The effects of using the Ward method have been presented in the form of a cluster tree - dendrograms (using Statistica 13.1). Analysis using Ward's method made it possible to combine the voivodeships which are the most similar to each other and which are at the same time maximally different from each other in terms of the distinguished features determining the availability of public services. In the conducted study, a critical value was determined on the basis of the analysis of the graph of the course of agglomerations. After observing the largest increment, in which numerous clusters are formed approximately at the same connectivity distance, there is a cut-off dividing the set into classes.

To assess the level of availability of public services, a set of diagnostic variables was selected in the first stage, which characterize public services by type (administrative, social and technical). The selection of diagnostic variables meets three basic criteria: substantive, formal and statistical (Strahl, 2006). Taking into account the substantive and formal criteria and the current literature on the subject, a set of 32 diagnostic variables was proposed to examine the level of availability of public services in Polish voivodeships. Variables selected as diagnostic ones should have a high level of diversity and low correlation with other variables. In order to obtain the final set of variables, they were reduced on the basis of the coefficient of variation and using Hellwig's parametric method (Młodak, 2006; Szkutnik et al., 2015; Hellwig, 1968, pp. 307-326). Adopting the threshold value of the coefficient of variation at the level of $V \geq 10 \%$ resulted in eliminating from the set of potential diagnostic variables those for which the coefficient of variation reached lower values, i.e. the 4 following features: $X_{9}, X_{10}, X 18, X 29$. Then, Hellwig's parametric method was used. The threshold value of Pearson's correlation coefficient was arbitrarily set at $r^{*}=0.7$, which resulted in the elimination of 10 consecutive 
features from the set of variables ${ }^{8}$. In order to calculate a synthetic measure of the level of availability of public services, the following 18 diagnostic variables were finally adopted, with five being central variables and the remaining thirteen being isolated variables:

$X_{1}$ - Percentage of persons sending completed forms downloaded from the websites of public offices and institutions (in \%);

$X_{2}$ - Number of middle schools per $1 \mathrm{~km}^{2}$;

$X_{3}$ - Number of university students per 10,000 residents;

$X_{4}$ - Number of places in nurseries and child care centers per 1,000 children aged 0-3;

$X_{5}$ - Population per 1 doctor;

$X_{6}$ - Population per 1 dentist;

$X_{7}$ - Population per 1 nurse;

$X_{8}$ - Population per 1 midwife;

$X_{9}$ - Stationary social care facility per 1,000 residents;

$X_{10}$ - Number of museums per 10,000 residents;

$X_{11}$ - Educational events per 10,000 residents;

$X_{12}$ - Number of seats in permanent cinemas per 10,000 residents;

$X_{13}$ - Number of cultural events per 10,000 residents;

$X_{14}$ - Library book collection per 10,000 people;

$X_{15}$ - Density of commune road network with improved surface per $100 \mathrm{~km}^{2}$;

$X_{16}$ - Density of the poviat road network with a hard surface per $100 \mathrm{~km}^{2}$;

$X_{17}$ - Percentage of users of the sewage system (in \%);

$X_{18}$ - Length of active natural gas network in $\mathrm{km}$ per $100 \mathrm{~km}^{2}$.

Four variables are destimulants $\left(\mathrm{X}_{5}, \mathrm{X}_{6}, \mathrm{X}_{7}\right.$ and $\left.\mathrm{X}_{8}\right)$, while the others are 18 stimulants.

The indicators have been adjusted so that the results reflect the most important issues determining the level of availability to particular types of public services. Diagnostic variables selected to study the availability of public services characterize the following services by type: administrative, social and technical. The issue of availability of public services can be analyzed in the following aspects: economic, social and spatial. For the sake of this paper, the analysis of availability will be carried out in spatial and social terms (Dominiak, 2011). The measures of spatial availability calculated as the number of service establishments per $1 \mathrm{~km}^{2}$ and social availability expressed as the number of institutions providing services per number of residents were used for the analysis.

\footnotetext{
${ }^{8}$ The following features were eliminated from the study: Percentage of people searching for information on the websites of public offices and administrations (in \%); Percentage of people downloading forms from the websites of public offices and institutions (in \%); Number of primary schools per $1 \mathrm{~km}^{2}$; Number of general secondary schools per $1 \mathrm{~km}^{2}$; Places in stationary social care institutions per 1,000 residents; Density of the commune road network with hard surface per $100 \mathrm{~km}^{2}$; Density of the poviat road network with improved hard surface per $100 \mathrm{~km} 2$; Percentage of people using the natural gas network; Density of the active sewage system per $100 \mathrm{~km}^{2}$ and Number of vocational schools per $1 \mathrm{~km}^{2}$.
} 


\section{Availability of public services by voivodeship in Poland in 2014 and 2018 according to Hellwig's synthetic measure of development}

The classification of regions according to Hellwig's synthetic indicator showed a large variation in their availability (Table 1 and Figure 1). The difference between the maximum value of 0.565 (Małopolska region) and the minimum value of 0.065 (Lubuskie region) in 2014 amounted to 0.5 . In 2018, these values were as follows: maximum: 0.573, minimum: 0.070, i.e. the difference was 0.503 . The distance of the regions from the pattern of availability of public services in the years 2014 and 2018 is shown in Figure 1.

On the basis of the value of the synthetic measure, in 2018 compared to 2014, there was an increase in the overall level of availability of public services in twelve voivodeships, while a decrease was only recorded in four. Seven units improved their positions in the ranking of regions, three remained in the same positions and six voivodeships fell to lower positions. The calculated Hellwig's synthetic indicator for 2014 and 2018 was arranged in a linear order according to non-growing values and became the basis for distinguishing groups of voivodeships: with the highest (Group I), high (Group II), low (Group III) and very low (Group IV) level of availability of public services (Table 1). In both rankings, the group with the highest level of availability of public services is made up of the following regions: Małopolska and Mazowieckie, with the Śląskie voivodeship advancing to this group in 2018. The second group, with a high availability rate, consisted in 2014 of the following four voivodeships: Dolnośląskie, Podkarpackie, Śląskie and Łódzkie, and in the second analyzed year the presented group included Dolnośląskie and Podkarpackie voivodeships. A third group, which reflects a low level of availability, was dominant in terms of the number of featured regions in 2014, with ten voivodeships included. In 2018, the group in question, with Hellwig's indicator in the range of $0.134 \leq \mathrm{di}<0.269$, consisted of nine regions. In the last group, with a very low level of availability of public services, the Lubuskie region was included in both analyzed years, and in 2018 the Warmińsko-Mazurskie region joined this group, with the lowest value of Hellwig's indicator of 0.07 .

The best availability of public services among all the Polish regions is in Małopolskie and Mazowieckie voivodeships (Table 1). In both studied years, the level of availability placed them in the top two positions. However, a considerable distance between them was recorded in 2014: 0.132 , which nearly halved in 2018. The lowest level of availability of public services in both analyzed years was recorded in Lubuskie Voivodeship, for which the synthetic indicator was over 8 times lower than that the leader of the ranking in both 2014 and 2018 (8.7 and 8.1, respectively).

A relatively small group with a high availability of public services in 2014 was formed by the following voivodeships: Dolnośląskie, Podkarpackie, Śląskie and Łódzkie, the penultimate of which was promoted to Group I in 2018, while Lódzkie, maintaining the same — sixth 
position in both rankings, was in the group of voivodeships with a low availability. The most numerous group in 2014 was the one with a low level of availability of public services which included the following regions: Wielkopolskie, Świętokrzyskie, Podlaskie, Lubelskie, Zachodniopomorskie, Pomorskie, Kujawsko-Pomorskie, Opolskie and Warmińsko-Mazurskie, while the last region was included in the group with a very low level of availability closing the ranking in 2018. Both in 2014 and 2018 the group consisted of 9 units. The unfavorable change concerns the Lódzkie voivodeship, which left the group with a high availability level and joined the third group in 2018. However, the fact that the Łódzkie region took the top position in this ranking is positive. In the first analyzed year there was only one voivodeship in the group of voivodeships with a synthetic indicator in the range of: $\mathrm{di}<0.125$, whereas in 2018 , $(\mathrm{di}<0.134)$ the number of units in group IV increased to two. Invariably, in both analyzed years the latter group in terms of availability of public services consists of the Lubuskie region.

Table 1.

Values of taxonomic measure of availability of public services by groups I-IV in 2014 and 2018

\begin{tabular}{|c|c|c|c|c|c|}
\hline Item & Voivodeship & $\begin{array}{c}\text { Indicator } \\
d_{i} \\
2014 \\
\end{array}$ & Item & Voivodeship & $\begin{array}{c}\text { Indicator } \\
d_{i} \\
2018 \\
\end{array}$ \\
\hline \multicolumn{6}{|c|}{ GROUP I } \\
\hline \multicolumn{3}{|c|}{$\begin{array}{l}d_{i} \geq 0.375-\text { voivodeships with the highest level } \\
\text { of availability of public services }\end{array}$} & \multicolumn{3}{|c|}{$\begin{array}{l}\mathrm{d}_{\mathrm{i}} \geq 0.403 \text { - voivodeships with the highest level of } \\
\text { availability of public services }\end{array}$} \\
\hline 1 & Małopolskie & 0.565 & 1 & Małopolskie & 0.573 \\
\hline 2 & Mazowieckie & 0.433 & 2 & Mazowieckie & 0.504 \\
\hline & & & 3 & Śląskie & 0.405 \\
\hline \multicolumn{6}{|c|}{ GROUP II } \\
\hline \multicolumn{3}{|c|}{$\begin{array}{l}0.250 \leq \text { di }<0.375 \text { - voivodeships with a high } \\
\text { level of availability of public services }\end{array}$} & \multicolumn{3}{|c|}{$\begin{array}{l}0.269 \leq \text { di }<0.403-\text { voivodeships with a high level } \\
\text { of availability of public services }\end{array}$} \\
\hline 3 & Dolnośląskie & 0.335 & 4 & Dolnośląskie & 0.342 \\
\hline 4 & Podkarpackie & 0.330 & 5 & Podkarpackie & 0.285 \\
\hline 5 & Śląskie & 0.324 & & & \\
\hline 6 & Łódzkie & 0.285 & & & \\
\hline \multicolumn{6}{|c|}{ GROUP III } \\
\hline \multicolumn{3}{|c|}{$\begin{array}{l}0.125 \leq \mathrm{di}<0.250-\text { voivodeships with a low } \\
\text { level of availability of public services }\end{array}$} & \multicolumn{3}{|c|}{$\begin{array}{l}0.134 \leq \mathrm{di}<0.269-\text { voivodeship with a low level of } \\
\text { availability of public services }\end{array}$} \\
\hline s7 & Wielkopolskie & 0.231 & 6 & Łódzkie & 0.265 \\
\hline 8 & Świętokrzyskie & 0.228 & 7 & Podlaskie & 0.262 \\
\hline 9 & Podlaskie & 0.212 & 8 & Świętokrzyskie & 0.254 \\
\hline 10 & Lubelskie & 0.195 & 9 & Pomorskie & 0.249 \\
\hline 11 & Zachodniopomorskie & 0.187 & 10 & Zachodniopomorskie & 0.235 \\
\hline 12 & Pomorskie & 0.177 & 11 & Kujawsko-Pomorskie & 0.224 \\
\hline 13 & Kujawsko-Pomorskie & 0.172 & 12 & Lubelskie & 0.200 \\
\hline 14 & Warmińsko-Mazurskie & 0.137 & 13 & Opolskie & 0.170 \\
\hline 15 & Opolskie & 0.130 & 14 & Wielkopolskie & 0.170 \\
\hline \multicolumn{6}{|c|}{ GROUP IV } \\
\hline \multicolumn{3}{|c|}{$\begin{array}{l}\text { di }<0.125 \text { - voivodeships with a very low level } \\
\text { of availability of public services }\end{array}$} & \multicolumn{3}{|c|}{$\begin{array}{l}\text { di }<0.134 \text { - voivodeships with a very low level of } \\
\text { availability of public services }\end{array}$} \\
\hline 16 & Lubuskie & 0.065 & 15 & Lubuskie & 0.092 \\
\hline & & & 16 & Warmińsko-Mazurskie & 0.070 \\
\hline
\end{tabular}

Source: own study based on (Local Data Bank of Statistics Poland; Wykorzystanie technologii..., 2014; 2018). 


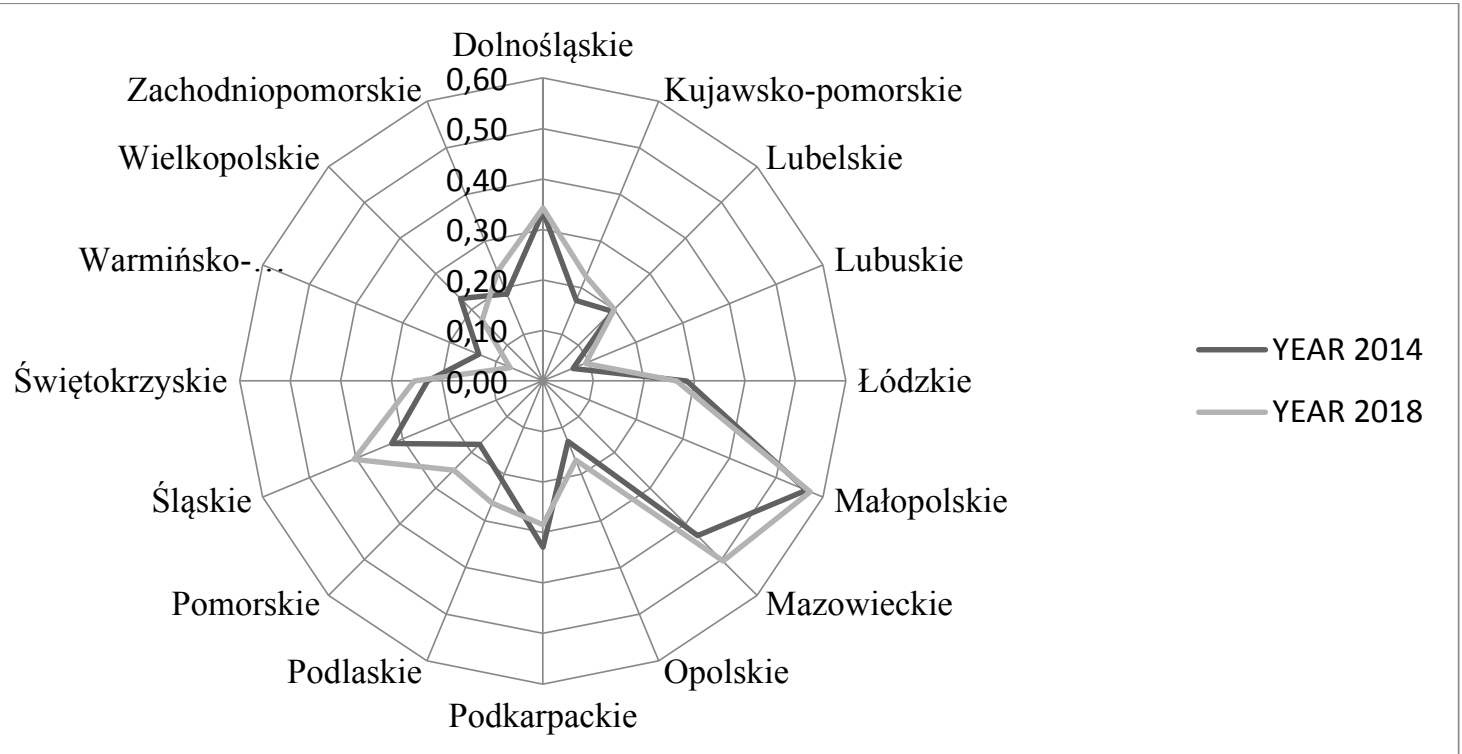

Figure 1. Classification of voivodeships in terms of the level of availability of public services in the years 2014 and 2018. Source: own study based on data from Table 1.

It should be noted that three of the eastern Poland voivodeships, i.e. Świętokrzyskie, Podlaskie and Lubelskie occupy, in both analyzed years, permanent positions in the group with a low level of availability, while Warmińsko-Mazurskie left this group in 2018 and found itself in group IV. Particular emphasis should be given to the Podkarpackie region, which escapes the characteristics of the eastern voivodeships and in both analyzed years maintained its position in the group with a high level of availability, despite a one-position drop in the ranking (from the 4th position in 2014 to the 5th in 2018) and a significant decrease in the synthetic indicator — by 0.045 point (i.e. by $13.6 \%$ ).

Spatial inequalities in the availability of public services in Poland are also evidenced by the number of territorial units in particular groups. In the first of the analyzed years, six voivodeships were among the regions with the highest and high level of availability of public services (in 2018 - 5), and in 2018, a larger group was made up of regions representing group III and IV - with the lowest and low level of availability of public services (in the second of the analyzed years - 11 units in total).

\section{Clustering of voivodeships in terms of availability of public services using Ward's method}

An important element of cluster analysis is cutting off the dendrogram, which allows to determine the number of clusters in the analyzed study. In the conducted study on the availability of public services an attempt was made to determine the critical value on the basis of the analysis of the linear connectivity distance graph in relation to subsequent stages of the connecting process. 
The analysis of the graph of the course of agglomerations for 2014 allows to draw conclusions that the place of the division of the dendrogram should be placed on the 15th step (the longest vertical line in Figure 2), i.e. the connectivity distance is between 9 and 12. For the study the cut-off point of the dendrogram for the connectivity distance of 9 was adopted.

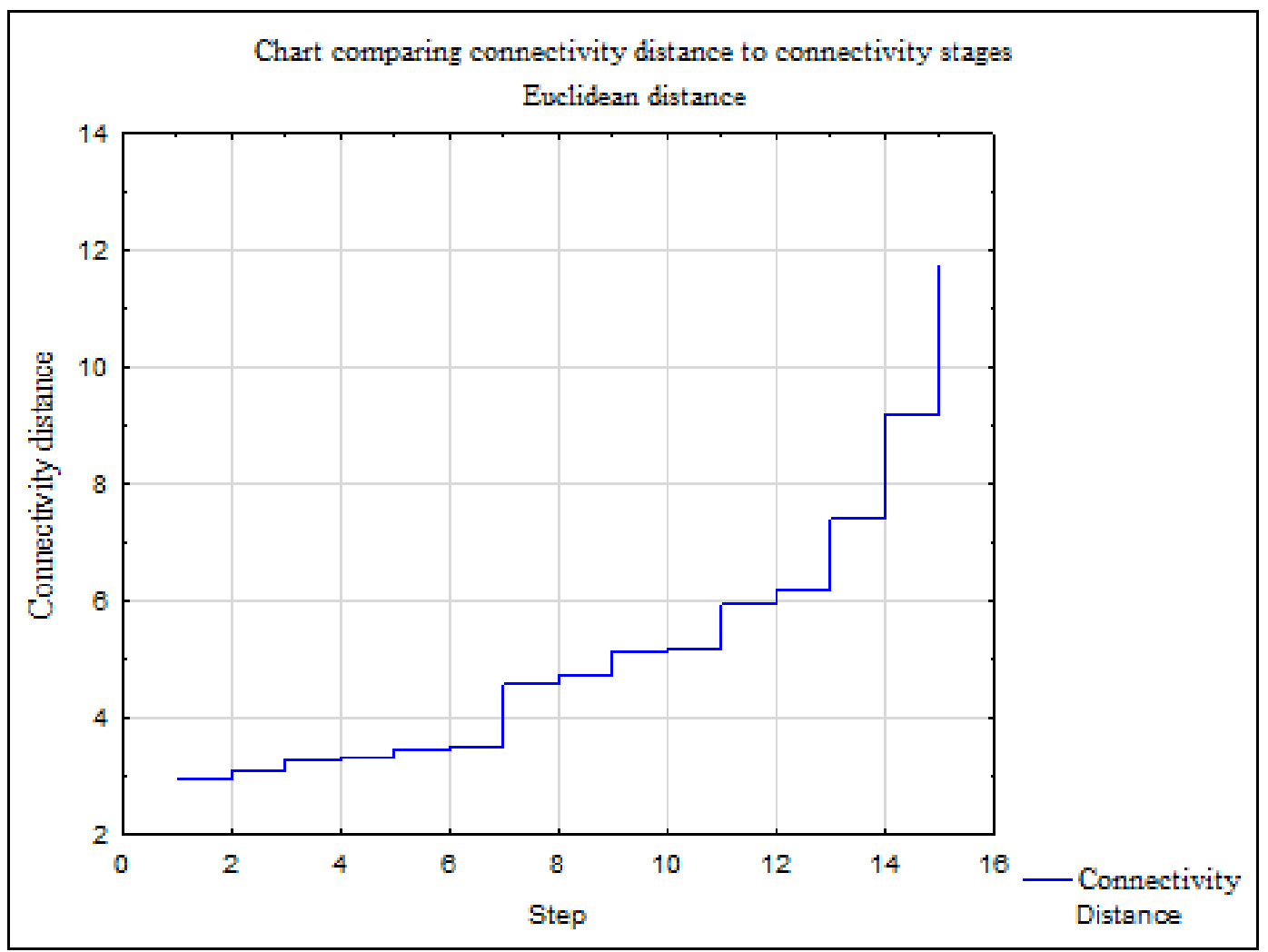

Figure 2. Diagram of the course of agglomeration for 2014. Source: own study based on (Local Data Bank of Statistics Poland; Wykorzystanie technologii..., 2014; 2018).

On this basis, three clusters were identified in 2014 (Figure 3). In the classification of the regions: two-, five- and nine-element groups were formed. The first cluster was formed by the following voivodeships: Dolnośląskie, Kujawsko-Pomorskie, Wielkopolskie, Pomorskie and Śląskie. The second, two-element cluster is made up of Małopolskie and Mazowieckie voivodeships. The structure of the third group, the largest in number, includes: Lubelskie, Łódzkie, Podkarpackie, Podlaskie, Lubuskie, Zachodniopomorskie, Warmińsko-Mazurskie, Opolskie and Świętokrzyskie voivodeships. 


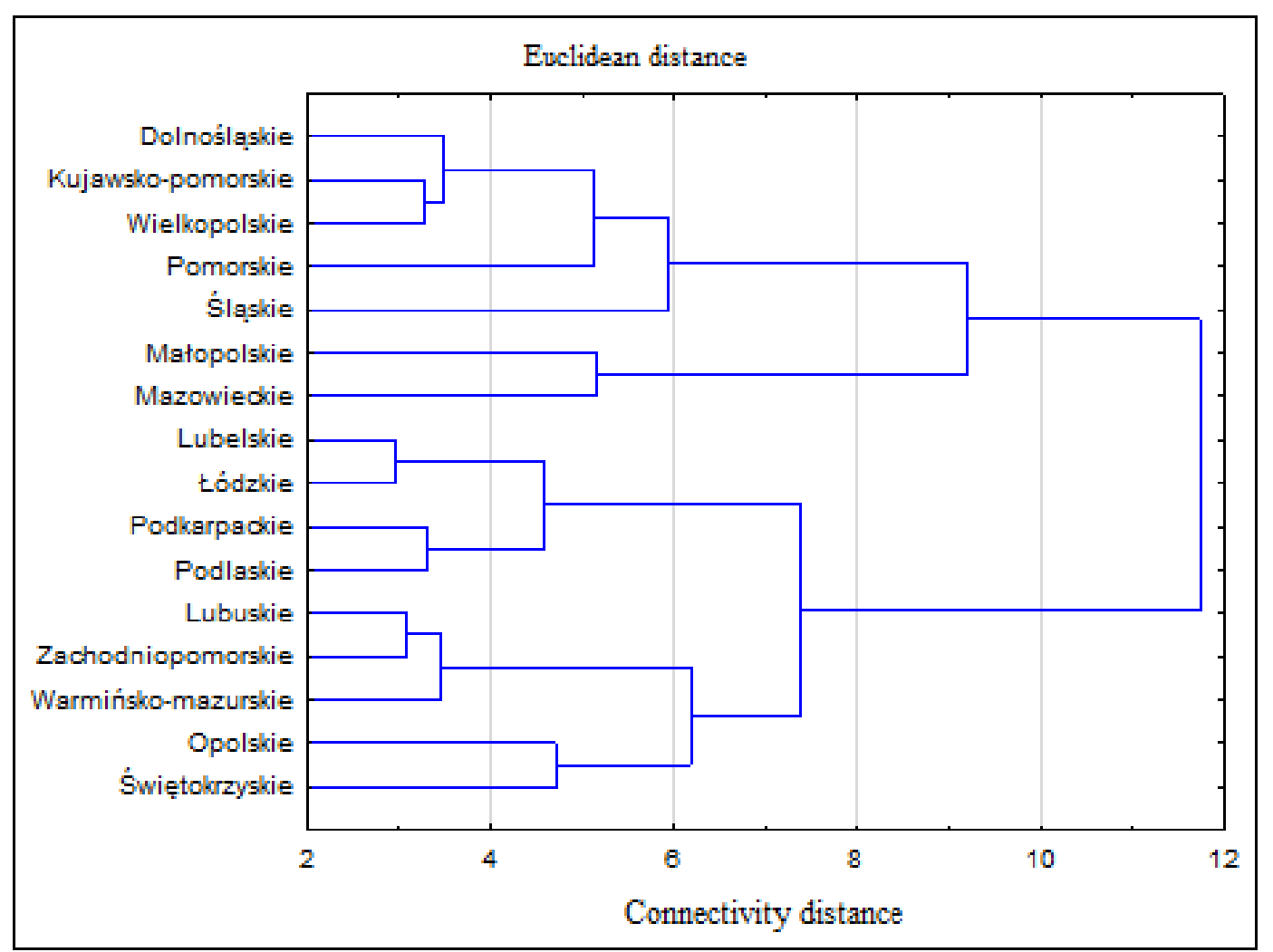

Figure 3. Cluster of Polish voivodeships with a similar level of availability of public services in 2014. Source: own study based on (Local Data Bank of Statistics Poland; Wykorzystanie technologii..., 2014; 2018).

On the basis of the analysis of the graph of the course of agglomeration for 2018, it can be concluded that the place of the division of the dendrogram is on the 13th step (the longest vertical line in Figure 4) i.e. the connectivity distance is between 6 and 9. The division of dendrogram for the connectivity distance of 6 became the basis for separating five groups of relatively homogeneous units, and among them: one-, two-, three-, four- and six-element ones. 


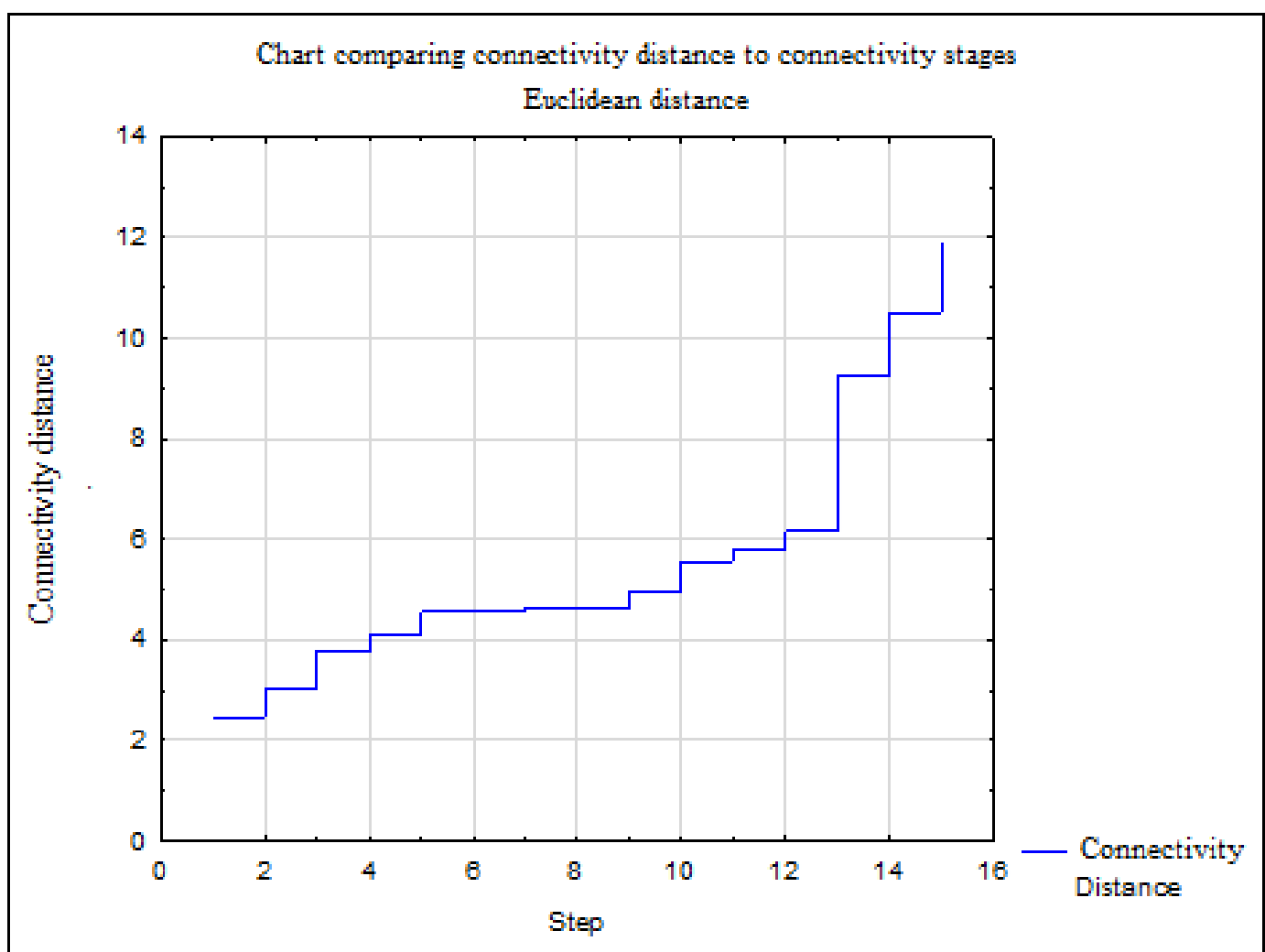

Figure 4. Diagram of the course of agglomeration for 2018. Source: own study based on (Local Data Bank of Statistics Poland; Wykorzystanie technologii..., 2014; 2018).

The first group included voivodeships which were separated due to their membership in the group of voivodeships with a high level of availability (Dolnośląskie) and a low level of availability (Wielkopolskie, Pomorskie) - Figure 5. The second cluster was made up of two voivodeships - Małopolskie and Mazowieckie, both representing the highest level of availability (Group I). The next, third cluster included the largest number of voivodeships, with six units: Kujawsko-Pomorskie, Łódzkie, Lubelskie, Podkarpackie, Podlaskie and Świętokrzyskie, apart from Podkarpackie (Group II) all of them represented a group of voivodeships with a low level of availability to public services. A separate, independent cluster was formed by Śląskie voivodeship, which in the taxonomic analysis was classified among the units with the highest level of availability. The last, fifth cluster characterizes the following voivodeships: Lubuskie, Zachodniopomorskie, Opolskie and Warmińsko-Mazurskie. 


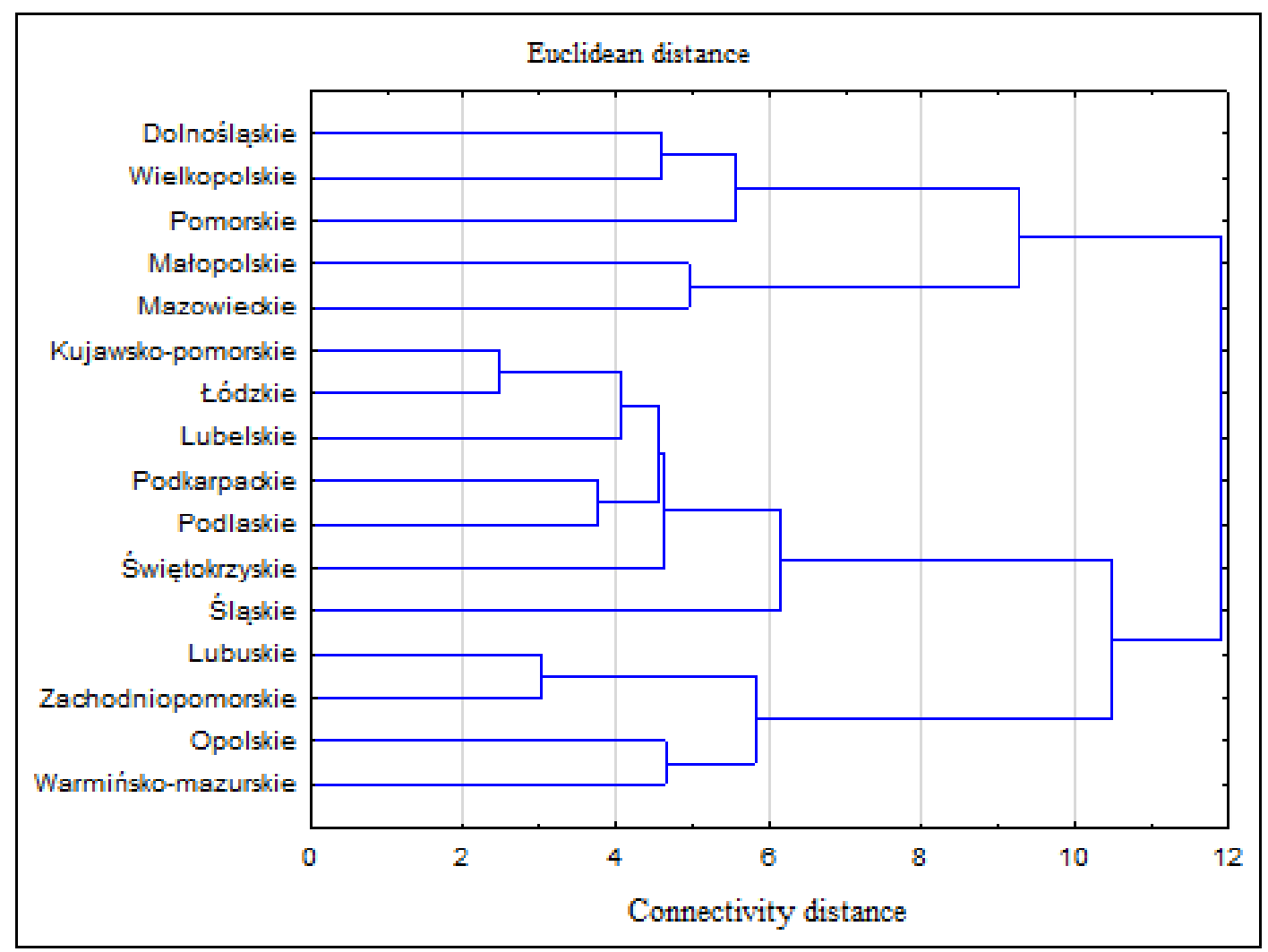

Figure 5. Similarity of Polish voivodeships in terms of the level of availability of public services in 2018 based on Ward's method. Source: own study based on (Local Data Bank of Statistics Poland; Wykorzystanie technologii..., 2014; 2018).

It is particularly noteworthy that in both of the analyzed years, the Małopolska and Mazowieckie regions formed a two-element group, which means that they clearly differ in terms of availability of public services from other units. The separation of voivodeships shown in the analysis using Ward's method coincides with the results of the taxonomic analysis in which these regions belonged to the least numerous group of objects with the highest availability of public services.

\section{Conclusions}

The study of availability of public services, as already mentioned, is an important component of the assessment of the level of social and economic development of territorial units and the standard of living of local communities. Therefore, it is justified to determine the essence of spatial diversity of the level of availability of public services, which play an important role in shaping the level of social and economic development of territorial units. The results of the research can be used in the process of management of public services by public administration units in the context of increasing the universal availability of these services and improving their quality. 
The carried-out analysis leads to the following conclusions:

Regions of Poland are characterized by a diverse level of availability of public services. The distance between the highest and the lowest ranked voivodeships indicates quite significant territorial inequalities in access to public services, although with the passing of the analyzed years they decrease slightly. The level of availability measured using a synthetic indicator showed the distance between the ranking leader (Małopolskie voivodeship) and the regions which ranked last (Lubuskie and Warmińsko-Mazurskie voivodeships) as above 1:8 in both analyzed years. The vast majority of Polish voivodeships were characterized by a low and very low level of availability of public services (10 units) in 2014, which did not change in 2018 this group included as many as 11 regions.

In both studied years, the highest level of availability to public services was observed in Małopolskie and Mazowieckie voivodeships, while the lowest in Lubuskie and WarmińskoMazurskie voivodeships. Małopolskie and Mazowieckie voivodeships are building their advantage thanks to well-developed public services in the field of education, health and social care, culture, transport as well as water and sewage infrastructure. A significant change was observed in the case of Dolnośląskie, Podkarpackie and Śląskie regions. While the former fell from 3rd position in 2014 to 4th position in 2018, it remained in the group with a high level of availability to public services, and slightly increased the value of its synthetic indicator. Similarly, the latter, although it fell from the 4th position in 2014 to the 5th position in 2018 , it retained its position in Group II, with a 0.035-point decrease in the synthetic indicator value. The advancement of Śląskie voivodeship to Group I was determined by: high positions in the development of sewage and gas infrastructure, improvement of the situation with regards to educational activities and transport infrastructure.

The presented methods - cluster analysis and linear ordering - group voivodeships in a similar manner in relation to the level of availability of public services. It is worth noting that the Małopolskie and Mazowieckie voivodeships, which constitute a separate two-element cluster in the cluster analysis, occupy the position of the leader and runner-up in the ranking created using the linear ordering method. The taxonomic analysis confirmed the diversity of availability to public services, the high ranking position of Małopolskie and Mazowieckie voivodeships and the low ranking position of Lubuskie and Warmińsko-Mazurskie voivodeships. 


\section{References}

1. Borowiec, L. (207). Controlling $w$ realizacji usług publicznych gminy. Kraków: Oficyna a Wolters Kluwer business.

2. Czerska, M. (2005). Obsługa interesanta w urzędzie miasta: stan i kierunki doskonalenia. Współczesne Zarzadzanie. No. 4, pp. 5-13.

3. Dominiak, J. (2011). Dostępność ustug publicznych na terenie województwa wielkopolskiego. Poznań: Instytut Geografii Społeczno-Ekonomicznej i Gospodarki Przestrzennej UAM. Available online http://www.wrot.umww.pl/wp-content/uploads/ 2015/09/1.Dost \%C4\%99pno\%C5\%9B\%C4\%87-us\%C5\%82ug-publicznych-na-tereniewojew\%C3\%B3dztwa-wielkopolskiego.pdf, 9.06.2020.

4. Dylewski, M., Filipiak, B. (2005). Usługi publiczne. In: S. Flejterski, A. Panasiuk, J. Perenc and G. Rosa. (Ed.), Współczesna ekonomika usług (pp. 451-454). Warszawa: PWN.

5. European Commission, Services of general interest, including social services of general interest: a new European commitment, $\operatorname{COM}(2007) 725$, final.

6. Flejterski, S., Panasiuk, A., Perenc, J., and Rosa, G. (Ed.) (2005). Współczesna ekonomika ustug. Warszawa: Wydawnictwo Naukowe PWN.

7. Gatnar, E., Walesiak M. (2004). Metody statystycznej analizy wielowymiarowej $w$ badaniach marketingowych. Wrocław: Wydawnictwo Akademii Ekonomicznej we Wrocławiu.

8. Hellwig, Z. (1968). Zastosowanie metody taksonomicznej do typologicznego podziału krajów ze względu na poziom ich rozwoju oraz zasoby i strukturę wykwalifikowanych kadr. Przeglad Statystyczny, XV(4), pp. 307-326.

9. Hellwig, Z. (1972). Procedure of Evaluating High-Level Manpower Data and Typology of Countries by Means of the Taxonomic Method. In: Z. Gostowski (Ed.), Towards a System of Human Resources Indicators for Less Developed Countries. Papers Prepared for a UNESCO Research Project (pp. 115-137). Wrocław: Ossolineum — The Polish Academy of Sciences.

10. Kos, B. (2015). Nowoczesne rozwiązania w usługach publicznych na przykładzie miejskiej karty elektronicznej. Problemy Zarządzania, Finansów i Marketingu, 40, Zeszyty Naukowe Uniwersytetu Szczecińskiego, Katowice: pp. 147-159. doi: 10.18276/pzfm.2015.40-12.

11. Koźlak, A. (2012). Nowoczesny system transportowy jako czynnik rozwoju regionalnego w Polsce. Gdańsk: Wydawnictwo Uniwersytetu Gdańskiego.

12. Kożuch, B., and Kożuch, A. (2011). Istota współczesnych usług publicznych. In: B. Kożuch, and A. Kożuch (Eds.), Ustugi publiczne. Organizacja i zarządzanie (pp. 3244). Kraków: Instytut Spraw Publicznych Uniwersytetu Jagiellońskiego. 
13. Krajowa Strategia Rozwoju Regionalnego 2030. Rozwój społecznie wrażliwy i terytorialnie zrównoważony (2019). Warszawa. Available online https://www.gov.pl/web/funduszeregiony/krajowa-strategia-rozwoju-regionalnego, 11.06.2020.

14. Local Data Bank of Statistics Poland. Available online http://www.stat.gov.pl, 24.05.2020.

15. Marek, T. (1989). Analiza skupień w badaniach empirycznych. Metody SAHN. Warszawa: PWN.

16. Młodak, A. (2006). Analiza taksonomiczna w statystyce regionalnej. Warszawa: Difin.

17. Niedzielski, P. (2011). Innowacje w usługach. In: K.B. Matusiak (Ed.), Innowacje i transfer technologii. Stownik pojęć (pp. 113-114). Warszawa: PARP.

18. Panek, T. (2009). Statystyczne metody wielowymiarowej analizy porównawczej. Warszawa: Szkoła Główna Handlowa.

19. Pine, B.J., Gilmore, J.H. (2013). The experience economy: part, present and future. Handbook on the experience economy. In: J. Sundbo, F. Sorensen (Ed.), Handbook on the Experience Economy (pp. 21-44). Cheltenham: Edward Elgar Publishing Ltd.

20. Program Rzadowy Dostęność plus 2018-2025 (2018). Warszawa: Ministry of Infrastructure and Development Available online https://www.ncbr.gov.pl/fileadmin/POIR/ 3_1_1_1_2019/Dok_dodatkowe/16_Program_Dostepnosc_Plus.pdf, 24.05.2020.

21. Strahl, D. (2006). Metody oceny rozwoju regionalnego. Wrocław: Wydawnictwo AE im. O. Langego.

22. Szkutnik, W., Sączewska-Piotrowska, A., Hadaś-Dyduch, M. (2015). Metody taksonomiczne z programem STATISTICA. Katowice: Wydawnictwo Uniwersytetu Ekonomicznego.

23. Wańkowicz, W. (2004). Wskaźniki realizacji usług publicznych. Program Rozwoju Instytucjonalnego PAOW. Kraków: Małopolska Szkoła Administracji Publicznej Akademii Ekonomicznej.

24. Ward, J.H. Jr (1963). Hierarchical grouping to optimize an objective function. Journal of the American Statistical Association, Vol. 58(301). pp. 236-244.

25. Wojciechowski, E. (2012). Gospodarka samorzadu terytorialnego. Warszawa: Difin.

26. Wykorzystanie technologii informacyjno-telekomunikacyjnych w 2014 roku. Warszawa: Statistics Poland. Available online https://stat.gov.pl/obszary-tematyczne/nauka-itechnika-spoleczenstwo-informacyjne/spoleczenstwo-informacyjne/wykorzystanietechnologii-informacyjno-komunikacyjnych-w-przedsiebiorstwach-i-gospodarstwachdomowych-w-2014-r-,3,12.html, 24.05.2020.

27. Wykorzystanie technologii informacyjno-telekomunikacyjnych w 2018 roku. Warszawa: Statistics Poland. Available online https://stat.gov.pl/obszary-tematyczne/nauka-itechnika-spoleczenstwo-informacyjne/spoleczenstwo-informacyjne/wykorzystanietechnologii-informacyjno-komunikacyjnych-w-jednostkach-administracji-publicznejprzedsiebiorstwach-i-gospodarstwach-domowych-w-2018-roku,3,17.html, 24.05.2020. 
28. Zeliaś, A. (Ed.). (2000). Taksonomiczna analiza przestrzennego zróżnicowania poziomu życia w Polsce w ujęciu dynamicznym. Kraków: Wydawnictwo Akademii Ekonomicznej.

29. Ziębicki, B. (2007). Uwarunkowania oceny efektywności świadczenia usług użyteczności publicznej. Zeszyty Naukowe Wyższej Szkoły Ekonomicznej w Bochni, No. 6, pp. 149-165. 